\title{
Pelatihan Pembuatan dan Penggunaan Alat Peraga Matematika Untuk Membelajarkan Konsep dan Operasi Bilangan Bulat Bagi Guru-Guru Sekolah Dasar di Gugus IV Cakranegara
}

\author{
Sri Subarinah*, Laila Hayati, Amrullah, Sudi Prayitno, Junaidi \\ Mathematics Education Study Program, PMIPA Department, FKIP \\ Universitas Mataram, Mataram, Indonesia
}

Kata Kunci:

pengabdian pada

masyarakat, pembuatan dan penggunaan alat peraga matematika, bilangan bulat, guru sekolah dasar

\begin{abstract}
Abstrak: Latar belakang kegiatan pengabdian pada masyarakat ini adalah sedikitnya kegiatan pelatihan tentang alat peraga matematika yang dilakukan oleh guru-guru sekolah dasar di gugus IV Cakranegara. Tujuan kegiatan ini adalah memberikan pelatihan pembuatan dan penggunaan alat peraga matematika, khususnya untuk membelajarkan konsep dan operasi pada bilangan bulat. Matode pelatihan meliputi (1) penyajian materi, (2) demonstrasi, (3) pembuatan alat peraga secara berkelompok, (4) presentasi hasil kerja kelompok, dan (5) evaluasi dan tindak lanjut. Kegiatan pengabdian dilaksanakan dalam satu hari, bertempat di SDN 1 Cakranegara, dengan peserta sejumlah 26 orang guru SD. Hasil kegiatan ini adalah sebagai berikut: (1) tim pengabdian telah menyajikan konsep-konsep bilangan bulat, memperkenalkan alat peraga kartu bilangan bulat, dan permainan baris-berbaris, (2) seluruh peserta praktik membuat alat peraga modifikasi kartu bilangan secara berkelompok dua orang, dan (3) $92 \%$ peserta dapat memperagakan alat peraga yang dibuatnya dengan benar. Hasil angket menunjukkan bahwa seluruh peserta dapat memahami materi pelatihan, senang dengan tambahan ilmu yang langsung dapat diterapkan, dan berharap bahwa kegiatan pengabdian dapat berlangsung terus menerus sehingga kesulitankesulitan pembelajaran matematika dapat diselesaiakan dengan efektif dan efisien
\end{abstract}

Korespondensi: srisubarinah.fkip@unram.ac.id

\section{PENDAHULUAN}

Pemerintah Indonesia, khususnya Departemen Pendidikan Nasional terus berupaya meningkatkan kualitas pendidikan matematika, baik melalui peningkatan kualitas guru matematika dengan pelatihan-pelatihan, maupun peningkatan prestasi belajar siswa melauli peningkatan standar minimal nilai ujian nasional. Namun, pada kenyataannya prestasi belajar matematika siswa pada jenjang pendidikan dasar dan menengah masih belum mengembirakan. Bahkan di tingkat dunia, pada pemeringkatan Programme for International Student Assessment (PISA) terakhir, kemampuan literasi matematika siswa Indonesia sangat rendah. Indonesia menempati peringkat ke-61 dari 65 negara peserta pemeringkatan. Menurut Firman Syah Noor (Nurfuadah, 2013), berdasarkan hasil penelitian Trends in International Mathematics and Science Study (TIMMS) yang dilakukan oleh Frederick K. S. Leung pada 2003, ada tiga penyebab utama mengapa indeks literasi matematika siswa di Indonesia sangat rendah. Penyebabnya adalah (1) lemahnya kurikulum di Indonesia, (2) kurang terlatihnya guru-guru Indonesia, dan (3) kurangnya dukungan dari lingkungan dan sekolah. Kurikulum pendidikan matematika di tanah air belum menekankan pada pemecahan masalah, melainkan pada hal-hal prosedural. Siswa dilatih menghafal rumus, tetapi kurang menguasai penerapannya dalam memecahkan suatu masalah, karena siswa biasa dilatih mengerjakan 
soal secara procedural tanpa pemahaman yang memadai terhadap materi pelajaran. Guru jarang bahkan tidak pernah menggunakan alat peraga di dalam menjelaskan konsep matematika sehingga siswa sulit memahami materi pelajaran matematika yang bersifat abstrak. Sedangkan anak usia SD, menurut Jean Piaget (Subarinah, 2006) masih berada pada tahap operasi kongkret, sehingga anak SD dalam belajarnya perlu memanipulasi benda-benda nyata sebagai obyek belajarnya. Hal ini sesuai dengan pendapat yang mengatakan bahwa matematika merupakan telaah tentang pola dan hubungan, suatu jalan atau pola berpikir, suatu seni, suatu bahasa dan suatu alat. (Reys, 1993). Dengan demikian penggunaan alat peraga dalam pembelajaran matematika di sekolah dasar itu penting.

Hasil penelitian Subarinah (2011) menunjukkan bahwa pembelajaran aktif, kreatif, efektif dan menyenangkan (PAKEM) dapat tercipta melalui Kopermatik (alat peraga matematika). Dan sebagian besar siswa (95.7\%) senang belajar matematuka menggunakan alat peraga Kopermatik. Hasil penelitian tersebut menunjukkan bahwa implementasi alat peraga Kopermatik mampu menciptakan suasana PAKEM di dalam pembelajaran matematika.

Gugus IV kecamatan Cakranegara terdiri dari enam sekolah, yaitu SDN 1 Cakranegara sebagai sekolah initi, SDN 9 Cakranegara, SDN 16 Cakranegara, SDN 20 Cakranegara, SDN 25 Cakranegara, SDN 34 Cakranegara. Berdasarkan hasil survei awal di SDN 1 Cakranegara yang dilakukan pada tanggal 6 Februari 2019 terhadap beberapa guru dan siswa, diperoleh hasil sebagai berikut. Pertama, sebagian besar guru masih kesulitan dalam pembelajaran matematika dengan memanfaatkan alat peraga. Kedua, sekolah hanya memiliki alat peraga bangun ruang dengan jumlah terbatas. Ketiga, guru tidak mempunyai ketrampilan dalam membuat alat peraga matematika. Sedangkan dalam membuat alat peraga matematika, terutama bangun-bangun geometri, dibutuhkan kecermatan dalam pengukuran dan model dasarnya (Subarinah, 2016). Keempat, siswa masih banyak yang kesulitan dalam hitung dasar bilangan bulat, khususnya yang berkaitan dengan bilangan bulat negatif. Kelima, siswa mengatakan senang jika dalam belajar matematika guru menggunakan alat peraga sambil bermain.

Pada survey pada tanggal 13 Februari 2019 yang dilakukan terhadap beberapa siswa dan diskusi dengan Kepala Sekolah SDN 1 Cakranegara dengan hasil sebagai berikut. Pertama, Kepala Sekolah di Gugus IV Cakranegara sangat antusias dalam menyambut adanya pelatihan pembuatan dan penggunaan alat peraga matematika karena selama ini belum pernah ada pelatihan serupa. Kedua, sekolah-sekolah di Gugus IV Cakranegara mempunyai beberapa alat peraga yang diberikan pemerintah, tetapi jarang bahkan ada yang tidak pernah digunakan karena tidak mengetahui cara penggunaanya. Ketiga, di sekolah-sekolah Gugus IV Cakranegara tidak ada yang mempunyai alat peraga matematika bilangan bulat. Keempat, sebagian besar siswa, bahkan yang berkemampuan tinggi, masih kesulitan dalam mengerjakan soal yang berkaitan dengan bilangan bulat.

\section{METODE KEGIATAN}

Metode/pendekatan yang akan diterapkan pada pengabdian pada masyarakat ini adalah diskusi dan demontrasi dalam membuat dan menggunakan alat peraga serta simulasi 
dalam pemanfaatan alat peraga dalam pembelajaran matematika terkait dengan materi bilangan bulat. Adapun urutan kegiatannya adalah sebagai berikut.

1. Presentasi dari Tim Pengabdian

Tim pengabdian memberikan materi tentang pentingnya alat peraga dan memberikan contoh penggunaan alat peraga bilangan bulat dalam pembelajaran di kelas serta cara membuat alat peraga bilangan bulat.

2. Diskusi tentang materi yang disampaikan Tim Pengabdian

Peserta diberikan kesempatan untuk bertanya dan menyampaikan pendapat tentang materi yang disampaikan oleh Tim Pengabdian

3. Pembuatan alat peraga

Peserta berkelompok dua orang praktek membuat alat peraga kartu bilangan dengan bentuk bebas (tidak harus berbentuk persegi panjang)

4. Simulasi dalam pemanfaatan alat peraga dalam pembelajaran matematika

5. Presentasi dari kelompok peserta

6. Masukan dari Tim Pengabdian.

\section{HASIL DAN PEMBAHASAN}

Kegiatan pengabdian pada masyarakat dalam bentuk pelatihan pembuatan dan penggunaan alat peraga dilaksanakan pada hari Jumat tanggal 23 Agustus 2019. Peserta kegiatan ini adalah 26 orang guru kelas 1 sampai 6 dari SD di Gugus IV kecamatan Cakranegara terdiri dari enam sekolah, yaitu SDN 1 Cakranegara, SDN 9 Cakranegara, SDN 16 Cakranegara, SDN 20 Cakranegara, SDN 25 Cakranegara, SDN 34 Cakranegara. Kegiatan dilaksanakan di sekolah inti Gugus IV kecamatan Cakranegara yaitu SDN 1 Cakranegara.

Pelatihan diawali dengan penyajian materi tentang peran alat peraga dalam pembelajaran matematika di sekolah dasar. APM diperlukan untuk menjembatani pola berpikir siswa SD yang masih bersifat kongkrit dan semi kongkrit dengan ilmu matematika yang bersifat abstrak, terutama tentang bilangan bulat. Hal ini sesuai dengan pendapat Piget (dalam Subarinah, 2006, 2011) yang menyatakan bahwa anak usia SD masih berada pada tahap operasi kongkret, sehingga anak SD dalam belajarnya perlu memanipulasi benda-benda nyata sebagai obyek belajarnya. Dan menurut Bruner (dalam Reys, 1998) anak Sekolah Dasar perlu melakukan manipulasi objek, mengkonstruksi, menyusun objek konkrit, berinteraksi secara langsung dengan benda fisik sehingga pada tahap yang lebih tinggi anak mulai mampu menggunakan gambar untuk memahami situasi. Dengan demikian kegiatan pengabdian ini dapat dijadikan dasar guru dalam pempelajaran matematika untuk menjembatani cara berpiker siswa yang masih konkrit atau semi konkrit dengan ilmu matematika yang abstrak, sehingga bermanfaat untuk meningkatkan pemahaman siswa terhadap konsep-konsep matematika yang abstrak. 

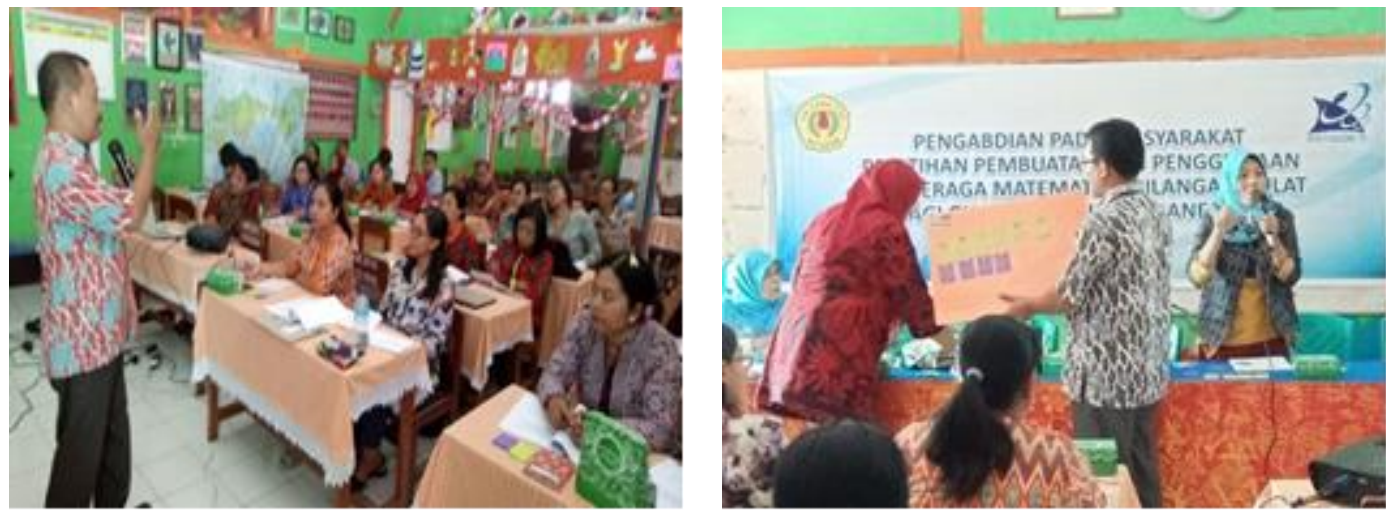

Gambar 1. Penyajian materi secara ceramah dan demontrasi

Penyajian materi dalam kegiatan pengabdian pada masyarakat ini menggunakan kombinasi metode ceramah, tanya jawab, dan demonstrasi (Gambar 1). Tim pengabdian pada masayarakat memulai penyajian materi dengan penjelasan tentang pentingnya APM, bilangan bulat, alat peraga bilangan bulat dan cara pembuatan, dan demonstrasi cara menggunakannya di kelas. Peserta pelatihan diberi kesempatan untuk bertanya atau menyampaikan pendapat sehingga terjadi diskusi multiarah, sehingga pemahaman peserta lebih mendalam dan tujuan kegiatan pengabdian pada masyarakat ini lebih efektif tercapai. Pada sesi ini, peserta sangat antusias berdiskusi, sehingga terjadi peningkatan pengetahuan dan pemahaman peserta tentang alat peraga bilangan bulat, cara pembuatan, dan cara penggunaannya di dalam pembelajaran matematika di kelas.
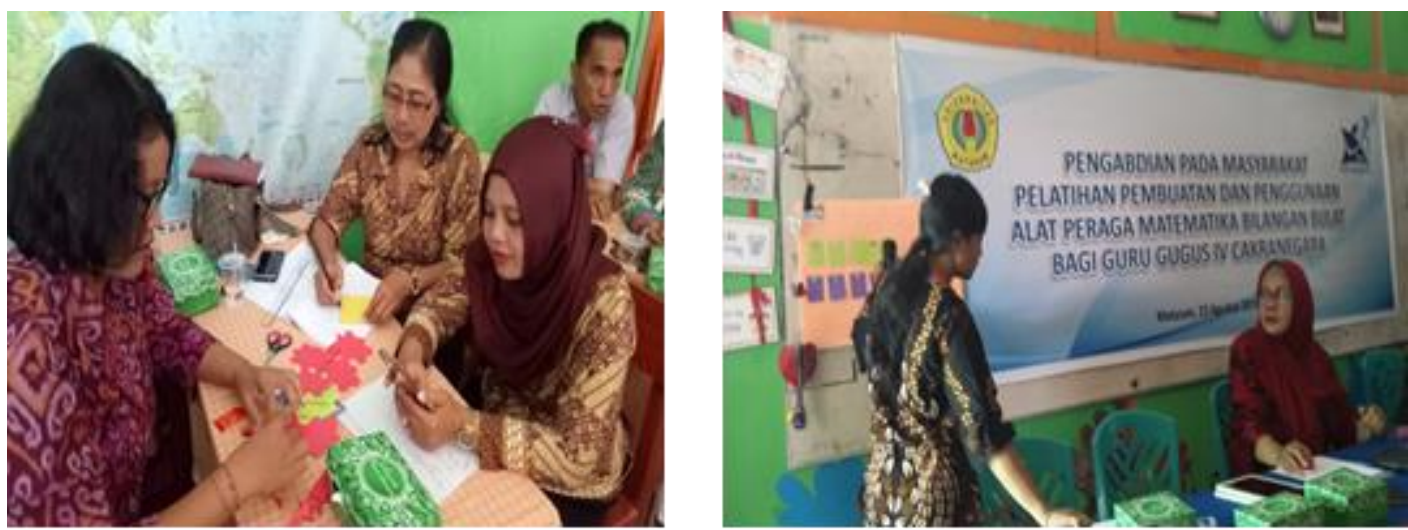

Gambar 2. Peserta membuat alat peraga kartu bilangan dan mempresentasi penggunaannya secara berkelompok

Kegiatan peserta dalam membuat dan menggunakan|alat peraga bilangan bulat, yaitu kartu bilangan difasilitasi dengan kegiatan praktek dan presentasi, seperti terlihat dalam Gambar 2. Peserta dibagi beberapa kelompok, setiap kelompok terdiri dua orang (satu meja), kemudian diberi tugas untuk membuat alat peraga bilangan bulat kartu bilangan. Peserta pelatihan sangat kreatif, sehingga alat peraga yang dibuat peserta sangat bervariasi bentuknya, walaupun contoh yang diberikan hanya berupa persegi panjang (Gambar 3). Dalam kegiatan praktik, peserta sangat antusias dalam mengerjakan pembuatan alat peraga. Setelah membuat alat peraga, peserta diberi kesempatan pratek menggunakan APM yang dibuat dengan cara presentasi oleh beberapa kelompok peserta di depan kelas. 

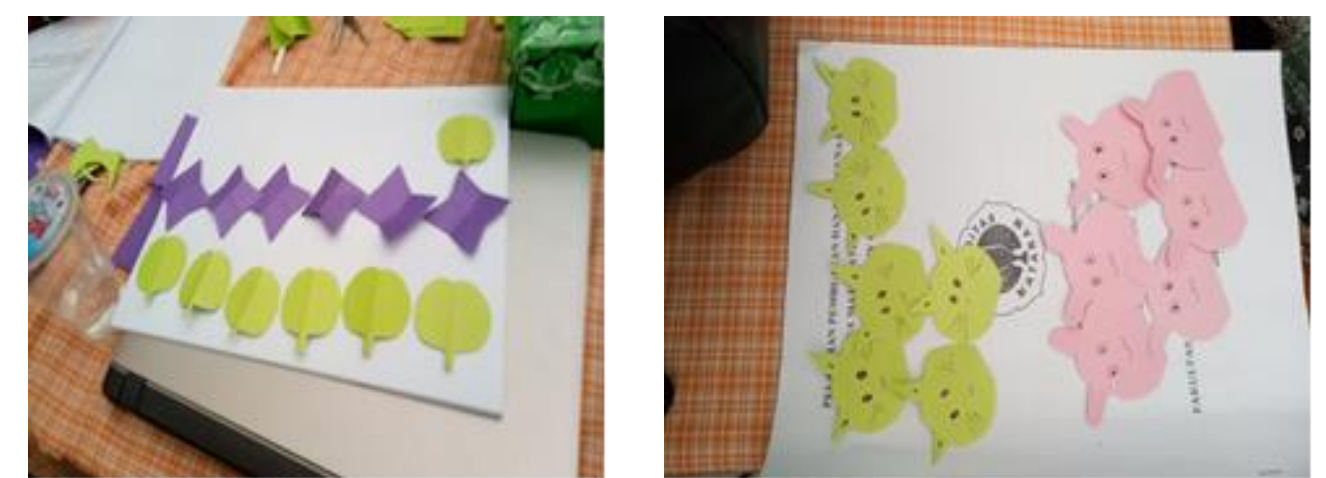

Gambar 3. Contoh alat peraga kartu bilangan yang dibuat perserta secara berkelompok

Alat peraga yang dikembangkan dalam kegiatan pengabdian ini termasuk alat peraga manipulatif. Menurut Russer (dalam Kelly, 2006) "children are active individuals who genuinely construct and modify their mathematical knowledge and skills through interacting with the physical environment, materials, teachers, and other children". Artinya, anak-anak aktif secara individual dalam mengkonstruksi dan memodifikasi pengetahuan dan keterampilan matematika yang murni/asli melalui interaksi dengan lingkungan, benda-benda nyata, guru, dan siswa lainnya. Dengan demikian alat peraga manipulatif yang dibuat dalam kegiatan pengabdian ini dapat dijadikan media interaktif siswa dalam membangun pengetahuan dan keterampilan matematikanya di dalam pembelajaran matematika di kelas.

Pada sesi terakhir kegiatan pengabdian pada masyarakat ini, peserta diminta mengisi angket untuk menilai kegiatan dan memberikan saran untuk rencana tindak lanjut. Dalam pengisian angket, identitas pengisi angket (nama dan asal sekolah) tidak dicantumkan agar lebih nyaman dalam mengisi angket. Berdasarkan hasil isian angket diperoleh data mengenai pengisi angket (kelas yang diajar), persepsi peserta terhadap kegiatan pengabdian ini, dan harapan peserta untuk kegiatan serupa di masa datang. Hasil isian angket adalah sebagai berikut.

1. Peserta pelatihan sebanyak 26 orang guru, yang terdiri dari 5 orang guru kelas 1,3 orang guru kelas 2, 2 orang guru kelas 3, 3 orang guru kelas 4, 4 orang guru kelas 5, dan 5 guru kelas 6 serta 3 kepala sekolah dan 1 orang guru agama.

2. Sebanyak $92 \%$ peserta pernah menggunakan APM dalam pembelajaran matematika sebelumnya, tetapi bukan alat peraga bilangan bulat, kebanyakan alat peraga bangun ruang dan frekuensinya tergolong jarang.

3. Seluruh peserta menyatakan dapat menerima materi dan melaksanakan praktik pembuatan dan pengunaan APM bilangan bulat dengan baik.

4. Seluruh peserta menyatakan bahwa kegiatan pengabdian pada masyarakat ini meningkatkan pengetahuan dan keterampilannya sehingga dapat meningkatkan kualitas pembelajaran matematika di kelas.

5. Seluruh peserta menyatakan bahwa APM yang dibuat dalam kegiatan pengabdian ini dapat dipraktekkan dalam pembelajaran matematika secara nyata di SD dan akan berdampak positif terhadap hasil belajar siswa, motivasi belajar siswa, suasana pembelajaran yang menyenangkan, dan karakter menghargai ilmu matematika. 
6. Seluruh peserta pelatihan menyatakan bahwa implementasi APM dalam pembelajaran matematika dapat berpengaruh positif tehadap karakter siswa dalam menghargai guru dan siswa lainnya.

7. Beberapa harapan guru tentang kegiatan pengabdian semacam ini adalah: (a) lebih sering dilakukan untuk menambah pengetahuan dan ketrampilan guru dalam APM, (b) materi pelatihan yang lain seperti pecahan dan sudut, (c) kegiatan pelatihannya dirancang berkelanjutan dan untuk forum yang lebih besar, (d) waktu dan materi pelatihan ditambah, Kegiatan seperti ini perlu untuk diadakan untuk meningkatkan pengetahuan dan kualitas guru.

\section{KESIMPULAN DAN SARAN}

\section{Kesimpulan}

Kegiatan pengabdian pada masyarakat ini telah efektif untuk meningkatkan pengetahuan dan keterampilan guru dan kepala sekolah SD di Gugus IV Cakranegara dalam membuat dan menggunakan APM bilangan bulat. Guru-guru dan kepala sekolah di Gugus IV Cakranegara sangat antusias mengikuti pelatihan ini. Hal ini ditunjukkan dengan kehadiran peserta (ada 26 orang) yang melebihi dari yang direncanakan yaitu sebanyak 20 orang guru. Aktivitas peserta dalam diskusi, pembuatan, dan presentasi penggunaan alat peraga berlangsung sangat bersemangat dan komunikatif. APM bilangan bulat yang dihasilkan dalam kegiatan pengabdian ini dalam berbagai bentuk yang lebih menarik dari contoh yang diberikan, karena peserta mempunyai jiwa kreativitas yang tinggi. APM bilangan bulat yang dicontohkan mudah dibuat dan digunakan, sehingga mempunyai nilai kepraktisan yang tinggi untuk diimplementasikan dalam pembelajaran matematika di sekolah dasar.

\section{Saran}

Saran dari kegiatan pengabdian pada masyarakat ini adalah (1) pembuatan APM dengan memahami cara pembuatan dan menggunakannya dapat dijadikan sebagai suatu cara untuk meningkatkan kompetensi guru, (2) pelatihan pembuatan APM masih perlu ditingkatkan kuantitas pelaksanaannya, yaitu penambahan materi dan waktunya, terutama sera jangkauan pesertanya, (3) dilaksanakan secara berkelanjutan sebagai motivasi guru untuk lebih kreatif untuk menerapkan pembelajaran yang menarik dan lebih memahami penggunaan APM

\section{Ucapan Terima Kasih}

Tim Pengabdian ini mengucapkan terima kasih kepada LPPM Unram yang memfasilitasi sehingga kegiatan pengabdian masyarakat ini dapat dilaksanakan dengan dukungan dana DIPA BLU Universitas Mataram tahun Anggaran 2019.

\section{DAFTAR PUSTAKA}

Kelly, C. A. 2006. Using Manipulative in Mathematical Problem Solving: A Performance Based Analysis. The Mathematics Enthusiast. Vol. 3, No. 2, 184-193.

Pitadjeng. 2015. Pembelajaran Matematika yang Menyenangkan. Yogyakarta: Graha Ilmu 
Nurfuadah, R. N. 2013. Penyebab Indeks Matematika Siswa RI Terendah di Dunia. http://news.okezone.com/read/2013/01/08/373/743021/penyebab-indeks-matematikasiswa-ri-terendah-di-dunia. Diakses tanggal 2 Februari 2019.

Reys, R. E. 1998. Helping Children Learn Mathematics. New York: A Viacom Company.

Subarinah, S. \& Prayitno, S. 2011. Penggunaan Kopermatik untuk mengimplementasikan dan mengembangkan pembelajaran (PAKEM). Jurnal Pendidikan dan Pembelajaran. Vol. 18, No. 1, hal. 98-106.

Subarinah, S. 2006. Inovasi Pembelajaran Matematiak Sekolah Dasar. Jakarta: Direktorat P2TK dan KPT Dikti.

Zilkova, K., Gucaga, J. \& Kopacova, J. 2015. (Mis)Conceptions About Geometric Shapes in Pre-Service Primary Teachers. Acta Didactica Napocensia, Vol. 8, No. 1, hal. 27-35. 